June - 2009

\title{
Virtual Spaces: Employing a Synchronous Online Classroom to Facilitate Student Engagement in Online Learning
}

\author{
J. Lynn McBrien and Phyllis Jones \\ University of South Florida \\ Rui Cheng \\ Nazareth College
}

\begin{abstract}
This research study is a collaborative project between faculty in social foundations, special education, and instructional technology in which we analyze student data from six undergraduate and graduate courses related to the use of a virtual classroom space. Transactional distance theory (Moore \& Kearsley, 1996) operates as our theoretical framework as we explore the role of a virtual classroom in distance education and analyze the ways in which a synchronous learning environment affects students' learning experiences. Elluminate Live! was the software employed in the virtual classroom. In this analysis, particular themes emerged related to dialogue, structure, and learner autonomy. In addition, students rated convenience, technical issues, and pedagogical preferences as important elements in their learning experiences. The article discusses these themes as a contribution to reducing the "distance" that students experience in online learning and to developing quality distance education experiences for students in higher education.
\end{abstract}

Keywords: Distance learning; synchronous online learning; transactional distance theory; virtual classroom

\section{Introduction}

Rapidly developing technology has facilitated distance education in all disciplines, and it has proven to be popular among students for various reasons, such as convenience and equal opportunity. As a result, many universities and colleges in the United States and around the world offer online degree programs and courses, which give students the opportunity to access higher education without leaving their homes (Butner, Murray, \& Smith, 1999). However, many students and researchers comment that distance learning courses lack interaction. Thus, improved teaching and learning strategies are needed to provide students not only the convenience of distance education but also the kind of access to real-time interaction with the instructor and class 
peers that simulates the traditional classroom setting. In fact, students have asked for more opportunities to interact with each other in synchronistic ways (West \& Jones, 2007).

The use of synchronous conferencing techniques can offer opportunities for social interaction in a virtual classroom space. Synchronous software popular in educational settings, such as Centra, HorizonLive, Elluminate Live!, and Interwise, share several interactive characteristics. They allow students and instructors to communicate orally, exchange messages through typing, upload PowerPoint presentations, transmit video, surf websites together, and more. However, because these synchronous systems are fairly new, they have not been studied extensively.

$\mathrm{Ng}$ (2007) reported the use of a synchronous e-learning system (Interwise) for online tutoring offered by Open University of Hong Kong. Interview data were collected from six tutors and eight students to examine teaching effectiveness and opportunities for interaction. The results indicated that both students and tutors were positive about using Interwise for online tutoring, and both student-teacher interaction and student-content interaction were perceived as successful through this platform. However, student-student interaction was minimal, several students cited technical difficulties that reduced their overall learning experience, and there was a mixed response regarding student preference (synchronous online versus traditional classroom). Both tutors and students regarded online tutorials as supplements to face-to-face tutorials.

Battin-Little, Passmore, and Schullo (2004) studied the use of Elluminate Live! (E!) by a group of nursing students, and the results showed that a majority of students rated E! in a positive way. It posed minor or no problems as long as student use of the technology was supported throughout the course. The study highlighted that students favored features such as emoticons, hand raising, a shared whiteboard, polling, and application sharing as points of personal engagement. Students talked about an enhanced learning experience, improved communication, high levels of satisfaction with the course, and strong group cohesion.

Although the student responses in these studies are positive to synchronic learning opportunities, more studies are needed to explore students' perceptions of the synchronous learning experience. The current study aims to make a contribution to the literature by analyzing qualitative student data that highlight pedagogical issues for higher education. Our research questions examined the following:

1. Do synchronous online platforms (specifically, Elluminate Live!) increase the social interaction that is missing in other, older forms of distance learning? Is this increase sufficient to create a positive learning experience for students?

2. What are the specific strengths and weaknesses of currently available synchronous online learning platforms, and what could be done to reduce the weaknesses?

This article discusses the insights gained from students about their experiences in a virtual classroom, which facilitates real-time interaction between learner-instructor, learner-learner, and learner-content. The intention of the research is to analyze distance by exploring the different elements of Moore's (1993) transactional distance theory, specifically dialogue, structure, and 
learner autonomy, through student responses to a survey about their experience with the synchronous online learning platform, Elluminate Live! (E!).

\section{Theoretical Framework}

One of the most prominent theories discussed in distance education is Moore's (1993) theory of transactional distance, which offers a framework for the current research into student perceptions of synchronous online learning. According to transactional distance theory, distance is considered a pedagogical phenomenon. The "sense of distance" a learner feels during the learning process transcends geography and is concerned with student interaction and engagement in the learning experience. This is particularly pertinent in an analysis of student perspectives of their own engagement in learning.

Transactional distance theory consists of three elements: dialogue, structure, and learner autonomy, all of which interrelate across learner-instructor, learner-learner, learner-content, and learner-interface interactions. Dialogue is defined as two-way communication and interaction in its many forms. Structure refers to course organization and the impact this has upon student engagement. Learner autonomy represents the learner's perception of both independent and interdependent participation in the course and is directly related to the student's level of selfdirected learning. For distance learning to be successful, Moore (1993) suggests that instructors need to pay attention to all three elements of transactional distance theory in order to reduce the "distance" experienced by the student.

Dialogue is an important element of all teaching and learning, but in distance education it presents a challenge. In online contexts, instructors must strive to optimize interaction between learner-instructor, learner-learner, and learner-content through effective modes of communication (Chen \& Willits, 1999; Jung, 2001; Moore, 1993). The facilitation of dialogue involves an evaluation of the opportunities for dialogue as well as an analysis of the quality of the dialogue that occurs.

All instructors adopt course structures and organization in their classrooms, both face-to-face and virtual; in transactional distance theory, "structure" represents the rigidity or flexibility of the course organization and course delivery. Moore (1993) asserts that the more rigid the course organization, structure, and delivery is, the higher the level of transaction distance experienced by the student.

Learner autonomy is a less obvious element of all teaching and learning but constitutes an essential element of transactional distance theory and student engagement in distance education. Online learning offers students the potential for more self-directed learning opportunities and flexible structures for engagement, which can increase student levels of autonomy, emotional independence, and self-direction (Belz \& Müller-Hartmann, 2003). Moore (1993) suggests that this is a crucial characteristic of student engagement in their learning, which naturally reduces their experience of "distance." 
Gorsky and Caspi (2005) asserted that Moore's theory is not a theory at all, but rather, a tautology that can be reduced to the following: "As understanding increases, misunderstanding decreases" (p. 8). They base their conclusion on a review of six quantitative studies that tested Moore's (1993) framework, and they found that each study supported the theory, but validity was poorly established. However, they also noted that the researchers involved in each study they reviewed suggested the need for qualitative measures in future studies.

In the current study, we are not so much attempting to validate Moore's theory as we are to discover what students identify as the strengths and weaknesses of this form of learning. However, we deemed the elements Moore references to be useful (and, at times, problematic, as we will discuss) in categorizing student responses.

E! is an example of synchronous software; it combines different tools into one interface creating a web-based classroom environment where a whole class or small groups of students, using headsets, can interact online in real-time. Such tools include text chat, two-way Voice-Over Internet Protocol (VOIP) audio, video, real-time presentation, breakout rooms for small group activities, white board presentations, class polling instruments, and application sharing. Synchronous online platforms offer instructors the potential for meaningful real-time interactions and improved opportunities for students to communicate at a geographical distance. Considering that dialogue requires two-way interaction, distance education tools involving virtual classrooms have the power to increase dialogue more than one-way methods of communication.

Synchronous online teaching supports careful planning and structuring of learning. For example, instructors can prepare a PowerPoint presentation to share during the live synchronous session. The technology is flexible enough to allow instructors to be responsive to students and to change teaching plans according to emerging student needs. This flexibility in structure is intended to decrease the transactional distance level between instructor and students.

The online platform that we adopted allowed us to provide immediate feedback to students and to facilitate constructive feedback between students themselves. Even with students who may not consider themselves self-directed or who may not have high learner autonomy, the friendly interface we adopted supported a range of various interactions to enable higher levels of student success.

\section{Research Design}

The authors, who are also the instructors, constructed a short, open-ended survey to collect student reflections about their experiences in our virtual classrooms. The survey was administered at the end of the course and was designed to capture succinct responses from students in a way that would highlight general themes to inform practice and future research (Cohen, Manion, \& Morrison, 2001). Our survey questions were the following:

1. What did you like about Elluminate?

2. What did you dislike about Elluminate? 
3. What worked? What didn't work?

4. Do you think I should use it again? Why? Why not?

The questions we chose to ask were intentionally broad as we did not want to lead students to answers that would directly correspond with Moore's (1993) theory. Rather, it was the process of analyzing emerging themes that caused us to address what Moore proposes as good practice in transactional distance theory.

\section{Context and Sample}

Participants in the project were enrolled in three undergraduate and three graduate courses in the College of Education at a regional campus of the University of South Florida. All of the courses were mandatory. We used opportunistic sampling to recruit participants (Silverman, 2000) from courses in social foundations and special education. Students were invited to voluntarily complete the survey as part of their evaluation of the course in addition to University-initiated evaluations. University evaluations do not include any reference to online learning. Table 1 illustrates the range of student and course information.

Table 1

Student and Course Information

\begin{tabular}{|l|l|l|l|}
\hline Department & Course & Academic level & $\begin{array}{l}\text { Number of } \\
\text { students }\end{array}$ \\
\hline Special Education & $\begin{array}{l}\text { Identification and } \\
\text { Assessment of Students with } \\
\text { Low Incidence Disabilities }\end{array}$ & Graduate & 14 \\
\hline Special Education & $\begin{array}{l}\text { Special Needs in the Early } \\
\text { Years }\end{array}$ & Undergraduate & 5 \\
\hline Special Education & Advanced Seminar & Graduate & 14 \\
\hline $\begin{array}{l}\text { Psychology/Social } \\
\text { Foundations }\end{array}$ & $\begin{array}{l}\text { Social Foundations of } \\
\text { Education }\end{array}$ & Undergraduate & 30 \\
\hline $\begin{array}{l}\text { Psychology/Social } \\
\text { Foundations }\end{array}$ & $\begin{array}{l}\text { Social Foundations of } \\
\text { Education }\end{array}$ & Undergraduate & 20 \\
\hline $\begin{array}{l}\text { Psychology/Social } \\
\text { Foundations }\end{array}$ & $\begin{array}{l}\text { Social and Economic } \\
\text { Foundations }\end{array}$ & Graduate & 7 \\
\hline
\end{tabular}

Each of the courses was web-enhanced and integrated virtual teaching and learning opportunities for the students. The number of synchronous online sessions in each course varied. Table 2 provides details about this variability and also illustrates the different delivery modes of each of the courses. From this table, it is clear that some students had more experience of virtual classrooms than other students. In fact, the majority of students in the social foundations courses who had only used E! twice responded that the course should either include more E! sessions or should not use the software because they felt that it took up to two class sessions to feel comfortable using it. 
Table 2

Mode of Delivery and Virtual Sessions per Course

\begin{tabular}{|l|l|l|}
\hline Course & Mode of delivery & Elluminate sessions \\
\hline $\begin{array}{l}\text { Identification and } \\
\text { Assessment of Students with }\end{array}$ & $\begin{array}{l}14 \text { week traditional schedule } \\
\text { Web-enhanced: } \\
\text { Asynchronous modules \& } \\
\text { Elluminate }\end{array}$ & 6 \\
\hline $\begin{array}{l}\text { Special Needs in the Early } \\
\text { Years }\end{array}$ & $\begin{array}{l}14 \text { week traditional schedule } \\
\text { Web-enhanced: } \\
\text { F2F \& } \\
\text { Elluminate }\end{array}$ & 3 \\
\hline Advanced Seminar & $\begin{array}{l}5 \text { full day and three evening non- } \\
\text { traditional schedule } \\
\text { Option: F2F and Elluminate for } \\
\text { each session }\end{array}$ & 6 \\
\hline $\begin{array}{l}\text { Undergraduate Social } \\
\text { Foundations courses }\end{array}$ & $\begin{array}{l}\text { Web enhanced: } \\
\text { Asynchronous, F2F, and Elluminate }\end{array}$ & 2 in each section \\
\hline $\begin{array}{l}\text { Social and Economic } \\
\text { Foundations }\end{array}$ & $\begin{array}{l}\text { Week summer session } \\
\text { Asynchronous, F2F, and Elluminate }\end{array}$ & \\
\hline
\end{tabular}

Every student participated in training for the adopted technology at the beginning of the course, and university instructional technology staff provided support at the beginning of each synchronous online session. Males were in the minority of students in all classes: three in the graduate foundations course and two each in the undergraduate foundations sections, plus one each in the Special Needs in the Early Years courses and the Advanced Seminar. We did not observe differences in answers by gender or by level (undergraduate or graduate).

\section{Process of Analysis}

Data was collected through paper surveys then typed into Microsoft Word documents so that each of us could code responses separately. This was initially completed per course and then across the data as a whole. Transactional distance theory (Moore \& Kearsley, 1996) offered a framework to make sense of the emerging data in relation to students' experiences of distance in the virtual classroom. Inter-rater reliability was developed through individual and collaborative coding and recoding of raw data, which is a process that has been applied effectively in collaborative research (Jones, West, \& Stevens, 2006). Through this process of inter-rater collaboration, other themes emerged in addition to those related to transactional distance theory that allow an added insight into student experiences of synchronous teaching and learning. 


\section{Results}

Ninety surveys were distributed and 62 were returned, showing a $69 \%$ return rate with variability across courses. Table 3 shows the return rates per course and it shows a good representation across courses.

Table 3

\section{Survey Return Rates per Course}

\begin{tabular}{|l|l|l|}
\hline Course & Surveys distributed & Surveys returned \\
\hline $\begin{array}{l}\text { Identification and Assessment } \\
\text { of Students with Low } \\
\text { Incidence Disabilities }\end{array}$ & 14 & 7 \\
\hline $\begin{array}{l}\text { Special Needs in the Early } \\
\text { years }\end{array}$ & 5 & 5 \\
\hline Advanced Seminar & 14 & 8 \\
\hline Social Foundations & 20 & 14 \\
\hline Social Foundations & 30 & 21 \\
\hline $\begin{array}{l}\text { Social and Economic } \\
\text { Foundations }\end{array}$ & 7 & 7 \\
\hline
\end{tabular}

Through the collaborative coding process, we highlighted transactional distance theory components - dialogue, structure, and learner autonomy - as we considered the ways in which E! might increase social interaction as well as the strengths and weaknesses of the learning experience. We then revisited the student responses to code any additional themes that emerged from the data independently of the theory. Table 4 illustrates the instances of each theme found by each of the authors.

Table 4

Rater Comparison

\begin{tabular}{|l|l|l|l|}
\hline Themes & Rater 1 & Rater 2 & Rater 3 \\
\hline Dialogue & 33 & 29 & 32 \\
\hline Structure & 43 & 39 & 43 \\
\hline Learner autonomy & 18 & 12 & 15 \\
\hline Technical difficulties & 53 & 51 & 55 \\
\hline Convenience & 43 & 46 & 49 \\
\hline Pedagogy & 43 & 48 & 40 \\
\hline
\end{tabular}

In discussions, we found that there is overlap between dialogue and pedagogy, structure and convenience, and learner autonomy and technical difficulties (with most of the reduced autonomy 
comments related to software and hardware issues). What follows is a discussion with examples of each theme.

\section{Dialogue}

Student comments about dialogue appear in remarks about comfort and student engagement. Only about 9\% (three comments) indicated a negative affect for dialogue. The majority of comments were positive (91\%), both in terms of quantity of dialogue from each student and the quality of dialogue experienced. Table 5 illustrates student data related to dialogue and demonstrates the range of responses, with the main thrust being positive.

Table 5

Example of Student Data for Theme of Dialogue

\begin{tabular}{|l|l|}
\hline Theme of dialogue & \multicolumn{1}{|c|}{ Student data } \\
\hline $\begin{array}{l}\text { Perceptions of comfort in the dialogue of the } \\
\text { virtual classroom }\end{array}$ & $\begin{array}{l}\text { "I felt comfortable talking to class members } \\
\text { and giving my presentation; it was like being in } \\
\text { a classroom." } \\
\text { "I learned a lot of information from the } \\
\text { sessions because I was so relaxed." }\end{array}$ \\
\hline $\begin{array}{l}\text { Student perceptions of engagement in dialogue } \\
\text { in the virtual classroom }\end{array}$ & $\begin{array}{l}\text { "I liked that everyone seemed to speak more." } \\
\text { "There seemed to be more participation from } \\
\text { classmates that are usually silent." } \\
\text { "I liked the way discussions were held since it } \\
\text { gave everyone an opportunity to talk." } \\
\text { "People express their points of view more } \\
\text { openly, and discussion becomes more } \\
\text { involved." } \\
\text { "Less people participated." } \\
\text { "Sometimes I felt disconnected to the rest of } \\
\text { the class." }\end{array}$ \\
\hline
\end{tabular}

Overall, most students rated E! positively as far as increasing dialogue and interaction between students and the instructor and increasing dialogue and interaction among students.

\section{Structure}

Within this theme, students shared their confusion about, for example, difficulties keeping up with simultaneous modes of communication and also the experience of being in a virtual classroom. Across the student data, we found a high number of comments related to convenience. Although not specifically discussed as structure by Moore (1993), we believe that this facet of 
synchronous online teaching best relates to his concept of structure, in this case physical structure. All of these comments focused on instructional ease due to the fact that students could remain at home for class, save on travel expenses, and attend class even when ill. Some students who had young children at home also commented that the online platform gave them the ability to attend to their families and still participate in class. Table 6 illustrates the different elements of structure with supporting student data.

Table 6

Example of Student Data for Theme of Structure

\begin{tabular}{|c|c|}
\hline Theme of structure & Student data \\
\hline Confusion experienced by students & $\begin{array}{l}\text { "Sometimes the chat got a little out of control. } \\
\text { People were typing so much at once that it was } \\
\text { hard to keep up." } \\
\text { "A bit confusing at times. Hard to always know } \\
\text { what the instructor was doing or when to speak, } \\
\text { answer questions." } \\
\text { "Once we were put into groups it was chaos. } \\
\text { We just did not know what to do." }\end{array}$ \\
\hline Experience of a virtual classroom & $\begin{array}{l}\text { "It gives you a break from the traditional } \\
\text { classroom experience. Sometimes you may sit } \\
\text { in the back of the room, but on E you have a } \\
\text { front row seat." } \\
\text { "It is nice to introduce to students being that it } \\
\text { is newer technology." } \\
\text { "It gives students an opportunity to learn in } \\
\text { different ways. Also it can give future online } \\
\text { teachers a feel of what they could be doing." }\end{array}$ \\
\hline Convenience & $\begin{array}{l}\text { "Since I would not have been able to take the } \\
\text { class if the majority of it was not offered } \\
\text { online, Elluminate offered a flexible classroom } \\
\text { option." } \\
\text { "It was easier for me because I have to be up at } \\
5 \text { a.m. for work and in class until } 9 \text { p.m." } \\
\text { "When I was sick I was able to stay in my PJ's } \\
\text { and still participate fully in class." } \\
\text { "It's so nice for parents/working students. I } \\
\text { cannot express how much I wish they offered } \\
\text { full-time classes on Elluminate." }\end{array}$ \\
\hline
\end{tabular}


Comments again indicate an increase of interaction, from simply being able to take the course to keeping up in spite of illness (which would prevent attendance in a traditional class). Positive pedagogy is indicated both by the idea that all students "have a front row seat" and that E! classes prepare future teachers to use new technologies.

\section{Learner Autonomy}

We found that the theme of learner autonomy was frequently double coded along with either convenience (thus, some independence in participation), student involvement (a sense of freedom in communication), or support of students processing concepts and content of the course. Thus, for us, this concept folded into structure and dialogue/pedagogy. Some students commented that the synchronous online system created opportunities for more advanced conversation and learning opportunities than might occur in a traditional classroom. Data related to technical issues that affected student involvement and engagement were mainly negative, with the majority detailing technical difficulties. These had to do with signing on to sessions, experiencing microphone problems, and occasionally being disconnected from the session. However, some students also discussed how the virtual classroom experience supported their engagement in the discussion. Convenience is detailed in Table 5 under structure but the other themes related to learner autonomy are illustrated in Table 7.

Table 7

Example of Student Data for Theme of Learner Autonomy

\begin{tabular}{|c|c|}
\hline Theme of learner autonomy & Student data \\
\hline Technical issues & $\begin{array}{l}\text { "Interactions with others were constrained by } \\
\text { technology. Frustrations signing on and getting } \\
\text { kicked off. Microphone troubles." } \\
\text { "TECHNICAL DIFFICULTIES. I personally } \\
\text { had audio issues but it was with my computer } \\
\text { and missing out on the classroom experience." }\end{array}$ \\
\hline Student involvement & $\begin{array}{l}\text { "It allows shy people to communicate their } \\
\text { opinions without being exploited. Takes the } \\
\text { pressure off giving opinions." } \\
\text { "I can make comments without feeling } \\
\text { awkward. Sometimes I do in class because I'm } \\
\text { shy." } \\
\text { "I felt like I could say anything without having } \\
\text { my answer judged. Sometimes I'm afraid to } \\
\text { answer in class." }\end{array}$ \\
\hline Supporting student processing of ideas & $\begin{array}{l}\text { "Talking through the microphone really helped } \\
\text { me to collect my thoughts, knowing that I } \\
\text { could only express myself verbally. It also }\end{array}$ \\
\hline
\end{tabular}




\begin{tabular}{|l|l|}
\hline & $\begin{array}{l}\text { made me feel more in control of how I } \\
\text { communicated my ideas because a large group } \\
\text { of people weren't staring at me, and this made } \\
\text { me more confident in how I expressed myself." } \\
\text { "I found that the class interacted more with the } \\
\text { topic than in class." } \\
\text { "Voting was great-great to see what everyone } \\
\text { else in class felt-you don't always get that } \\
\text { feedback." }\end{array}$ \\
\hline Negative impact on student involvement & $\begin{array}{l}\text { "So many things at once: PowerPoint, people } \\
\text { talking on the mike and people typing } \\
\text { messages. It was like CNN." } \\
\text { "Sometimes it was hard to keep up with the } \\
\text { messages, listening to commentators, and } \\
\text { reading the lesson." } \\
\text { "It was almost over-stimulating at times, which } \\
\text { caused me stress." } \\
\text { "Lack of interaction with peers and instructor." } \\
\text { "Lack of visual stimulation during lecture." } \\
\text { "We didn't do enough." }\end{array}$ \\
\hline
\end{tabular}

Clearly, the technical difficulties experienced by students, from poorly functioning microphones to the inability to $\log$ onto the site, constituted a major weakness. Additionally, students felt overwhelmed by the simultaneous methods of engagement. However, strengths of the platform were highlighted when students revealed that they felt more confident to comment when using an online platform and they recognized that the lack of non-verbal communication can stimulate students to reflect more and to be precise with their verbal responses.

In addition to the themes related to the framework of transactional distance theory, other themes emerged from the data. Similar to Ng (2007), we found that some students mentioned that they missed face-to-face classroom time:

Missing compadres.

I like to support others as they present by contributing verbally. Cannot do that on Elluminate and others could not support me when I was presenting.

I missed non verbal gestures.

These comments could, perhaps, be categorized with the element of dialogue, in this case nonverbal "dialogue" that results in a live social learning environment. It should be noted that more comments alluded to the comfort and sense of safety that resulted for some students who felt shy or "put on the spot" when commenting in a traditional classroom. 
In spite of numerous complaints about technological difficulties, 48 out of 62 responses indicated enthusiastic support for using a synchronous online environment again. Only five students said no, and nine were uncertain or gave qualifying responses. The affirmative data once again referred to convenience and the enhanced learning in terms of discussions, to pedagogical advantages such as increased interest, and to opportunities for familiarization with a new teaching/learning technology. The following comments are typical of these themes:

Yes, beneficial to students w/ kids and those w/ full-time jobs.

It was nice to have good discussions and to discuss materials.

Yes, use it again simply because of the interaction that takes place. You said last week that we had some good discussions - I most certainly agree.

Those students who were uncertain about using the technology again offered suggestions for implementation that would enhance learning, which were related to structure and organization. For example, one student wrote the following:

If used again, needs to be planned more carefully and maybe tried the first session with all of the students in the classroom, not home.

\section{Discussion}

In this study, one of our research questions was intended to address past concerns about insufficient social interaction in distance learning. Of course, it should be remembered that Moore's (1993) theory was formulated prior to the use of synchronous online learning platforms, and some of the past criticism can be attributed to the fact that early forms of distance learning (still in use today) did not include real-time meetings. Thus, we could expect that the use of technology that allows for real-time conversation, both audio and written, would be likely to decrease the "distance" incurred using asynchronous platforms. Beyond the issue of social interaction, we wanted to discover student-perceived strengths and weaknesses of using a platform such as Elluminate Live! with the hope that we could reduce perceived weaknesses and improve the learning experience.

Moore (1993) suggests that dialogue, structure, and learner autonomy form a triad of elements in transactional distance theory, which offers a way to understand notions of "distance" in online courses. Students' responses in this research provide insights into how participation in a virtual classroom using synchronous online classes affects these elements of transactional distance theory. In this section we reflect on each element separately. However, through the data analysis, we found many overlaps between the elements. This supports the notion that "distance" in online learning is a complex phenomenon that demands a holistic analysis. Here we concur with Gorsky and Caspi's (2005) criticism that Moore failed to offer operational definitions for the elements, with a result that it is sometimes difficult to clearly differentiate between them. 
Considering dialogue as communication and interaction, students shared their positive experiences of their time in a virtual classroom. The synchronous online system used at our university, Elluminate Live!, offers different modes of communication, which were perceived by most students to increase the amount of social interaction. Many students linked dialogue to important pedagogical considerations as well, such as increased participation and increased time to reflect before responding. Perhaps most importantly, the synchronous online platform allowed students, particularly shy students, to feel more comfortable expressing their opinions. This indicates the power of a synchronous online system to empower students in conversation and expression. Many of these students may never initiate comments in a traditional classroom. In such cases, the transaction distance enables such students to formulate their ideas and receive responses to them, thus increasing their learning potential.

Some students judged the screen interface, even with multiple transactions occurring at once, as inadequate. The activity that occurs on the screen is qualitatively different from the stimuli created by students and teachers in a traditional classroom. It may be that students making these comments perceive a lack of stimulus due to the loss of nonverbal communication and the lack of physical contact with their peers and instructor. Student responses in this project affirmed the work of Chen and Willits (1999) and Jung (2001), who show the value of supporting effective forms of interaction between learner-instructor, learner-learner, and learner-content. Student experiences in our virtual classrooms demonstrated that varied processes of real-time communication, which are sensitive to individual learning preferences, positively affected some student involvement in online learning. For example, we found that students who participated less in face-to-face $(\mathrm{F} 2 \mathrm{~F})$ classroom discussions participated more in synchronous online interactions, a change in their behavior that was noted by themselves and other students in their classes. However, we also heard from a smaller group of students (9\%) who felt that their interaction was negatively impacted and thus increased their "distance." Students in this group spoke of feeling "disconnected," and others talked about their frustration with technology glitches and how these glitches affected the quality of their interactions. Still other student comments suggested that the multitasking capability of the technology, including speaking, listening, writing, and viewing videos or PowerPoints, was often overwhelming. When multiple methods of communication occur simultaneously, it can be over-stimulating, with the result that some of the information transferred is overlooked by the students. Student data indicated that instructors must be vigilant and proactive regarding student interaction and communication throughout their time in the virtual classroom. Virtual classroom sessions can be recorded so that an instructor can go back and review student participation and interaction, and, if necessary, include additional supports for particular students in future classes. However, this level of instructor responsiveness can become a challenge when seats for online courses are increased.

Structure in transactional distance theory refers to course organization and the impact this has upon student participation (Moore, 1993). Structure is discussed on a continuum of flexibility to rigidity and Moore suggests that flexibility supports the reduction of distance between a learner and course material. Students in this research revealed the complexity of the issues related to rigidity and flexibility. They responded well to clear, tight, and transparent structures of organization, but some struggled when the virtual classroom features were employed in a less 
structured way. This suggests the need for clarity of understanding, or a clear operational definition, of what constitutes a flexible or rigid structure. Students revealed the need for clear and consistent structure, expectations, and roles in virtual classroom sessions to reduce their experience of distance. These responses seem to challenge Moore's (1993) contention that increased structure also increased transactional distance.

The final element of transactional distance theory is learner autonomy. Muller (2003) discusses student autonomy as being synonymous with notions of emotional independence and selfdirection. Students conveyed how the synchronous online classes offered them convenience, which increased their ability to participate in higher education. However, students also offered a strong insight into the impact of technical difficulties on their involvement and participation and thus on their capacity for emotional independence and self-direction. Clearly, in this study, we learned from students that technical issues have a strong impact on experiences of "distance" in online learning across all elements of the theory. The technical problems caused some students to feel that they had lost control, thus reducing their sense of autonomy. When technical problems arose, student learning was halted, and some students were shut out of entire classes because they could not fix the problem independently. In fact, in a couple instances, even help from Elluminate technicians was insufficient to solve immediate problems. As well, receiving technical help often prevented students from attending the entire class as they had to spend time with a technician to solve the problem.

As mentioned earlier, some students in this study discussed missing the face-to-face contact with peers, which points to the possibility that online learning is not their preferred form of learning and alludes to the qualitative difference between virtual and traditional classrooms. For some, the element of face-to-face human contact that is missing in the virtual classroom increases the transactional distance, reducing their sense of belonging and participation in class. This is an important lesson for instructors and calls for the need to build in technical training and support for students to reduce the negative impact of technical issues as well as to consider ways in which to include opportunities to simulate face-to-face interactions.

Our research is limited by the fact that we could only investigate the use of one synchronous online system. Additionally, it only reviews evaluations by a limited sample of students in education courses at one university. Further studies need to occur using larger samples, other subject courses, and other systems of synchronous online learning. Studies that compare several systems of synchronous online learning would also be beneficial to determine which platform components are most valuable to students.

Overall, students in this study were pleased with their learning experiences using E!. However, student perspectives gained from our findings indicate three clear problems in the studied online platform, which can inform further development of online learning. One was the confusion that resulted from too many simultaneous interactions, such as audio, typed chat, and whiteboard/PowerPoint or group questions that could be answered using emoticons, Yes/No, or multiple choice responses. This problem can be managed by the instructor. In E!, it is possible to determine the number of communication devices that can be used at any time. For instance, the 
typed chat feature can be turned off. It may be in large classes in particular that allowing only one type of communication at a time, or at least limiting the uses, could increase students' ability to attend.

Second, some students found that the lack of non-verbal communication reduced their educational experience. Given the increasing affordability of webcams, this issue might be resolved if the instructor and students installed webcams and used them during their online classes. E! now includes functionality for webcams. Finally, technology issues, from broken links to faulty headphones, continue to plague synchronous online classes. Institutions of higher learning that are implementing cost-reduction measures must not cut resources for web technicians or for professors who aim to develop high-quality web-based courses if they want to increase their distance learning offerings. In light of the rapid growth of online technologies, professors and students will always be in need of instruction to best utilize these ever-changing platforms.

There is an increasing impetus to create distance learning courses both at the university and secondary school levels, and it is critical for teachers to evaluate the ways in which they deliver online classes, so they can insure that quality does not suffer because of an over-emphasis on convenience. The current study, while not generalizable, suggests that most of our students had a positive online experience using synchronous learning technology. However, their concerns about too much stimuli, their desire for non-verbal communication, and their technological problems must be considered and overcome in order to create a positive learning experience for all students. 


\section{References}

Battin-Little, B., Passmore, D., \& Schullo, S. (2006, November/December). Using synchronous software in Web-based nursing courses. CIN: Computers, Informatics, Nursing. 24(6), 317-325.

Belz, J. A., \& Müller-Hartmann, A. (2003). Teachers as intercultural learners: Negotiating German-American telecollaboration along the institutional fault line. Modern Language Journal, 87, 71-89.

Butner, B.K., Smith, A. B., \& Murray, J. (1999). Distance technology: A national study of graduate higher education programs. Online Journal of Distance Learning Administration, 2(3). Retrieved May 2, 2007, from http://www.westga.edu/ distance/ojdla/fall23/butner23.html

Chen, Y., and Willits, F. K. (1999). Dimensions of educational transactions in a videoconferencing learning environment. American Journal of Distance Education, 13, 45-59.

Cohen, L., Manion, L., \& Morrison, K. (2001). Research methods in education. London: Routledge Falmer.

Gorsky, P., \& Caspi, A. (2005). A critical analysis of transactional distance theory. The Quarterly Review of Distance Education, 6(1), 1-11.

Huberman, A. M., \& Miles, M. B. (1994). Data management and analysis methods in education. London: Sage Publications.

Jones, P., West, E., \& Stevens, D. (2006) "I realized I knew nothing, that I had an awful lot to learn, and that I would have to help others see teachers in a different light": An international perspective on effective moments of teacher learning. British Journal of Special Education, 33(2), 82-90.

Jung, I. (2001). Building a theoretical framework of Web-based instruction in the context of distance education. British Journal of Educational Technology, 32, 525-34.

Moore, M. G. (1993). Theory of transactional distance. In D. Keegan (Ed.), Theoretical principles of distance education. New York: Routledge.

Moore, M. G., \& Kearsley, G. (1996). Distance education: a systems view. Belmont: Wadsworth.

Ng, K. C. (2007). Replacing face-to-face tutorials by synchronous online 
technologies: Challenges and pedagogical implications. International Review of Research in Open and Distance Learning. Retrieved July 2, 2008, from http://eric.ed.gov/ERICDocs/data/ericdocs2sql/content_storage 01/0000019b/80/28/08/7 $\underline{0 . p d f}$

Silverman, D. (2000) Doing qualitative research. London: Sage.

Smeaton, A.F., \& Keogh, G. (1999). An analysis of the use of virtual delivery of undergraduate lectures. Computers \& Education, 32, 83-94.

West, E., \& Jones, P., (2007). A framework for planning technology used in teacher education programs that serve rural communities. Rural Special Education Quarterly, 26(4), 3-15.

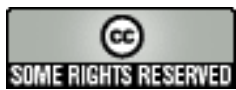

